\title{
Transposon-916-like Elements in Clinical Isolates of Enterococcus faecium
}

\author{
By HANSEL M. FLETCHER, * LAURA MARRI $\dagger$ \\ AND LOLITA DANEO-MOORE \\ Department of Microbiology and Immunology, Temple University School of Medicine, \\ Philadelphia, PA 19140, USA
}

(Received 15 March 1989; revised 7 August 1989; accepted 10 August 1989)

\begin{abstract}
Tetracycline ( $\mathrm{Tc}$ ) resistance was found in nine out of ten clinical isolates of Enterococcus faecium. Conjugative transposons, designated Tn5031, Tn5032 and Tn5033, were present in the chromosome of three isolates. The transposons were similar both structurally and functionally to Tn916 containing the tet $M$ determinant. A large non-conjugative plasmid found in a fourth isolate contained an element homologous to $\mathrm{Tn} 916$. The four isolates containing the element showing homology to $\mathrm{Tn} 916$ exhibited a substantially higher level of Tc resistance than the remaining five Tc-resistant isolates. Tc-resistance genes which have not been identified are apparently responsible for the low-level $\mathrm{Tc}$ resistance in five clinical isolates.
\end{abstract}

\section{INTRODUCTION}

In the genus Enterococcus there has been an increase in the frequency of reports of multiple antibiotic resistance (Finland, 1979). The markers most frequently carried by these strains include those encoding resistance to tetracycline (Tc), penicillin (Pen), erythromycin (Em), kanamycin $(\mathrm{Km})$, chloramphenicol $(\mathrm{Cm})$ and streptomycin $(\mathrm{Sm})$ (Finland, 1979; Le Bouguenec \& Horodniceanu, 1982). In this study, we examined clinical isolates of Enterococcus faecium that are resistant to a variety of antibiotics for a possible relationship between a putative conjugative element and resistance to several antibiotics. In an earlier study, Le Bouguenec \& Horodniceanu (1982) found that six out of ten clinical isolates of E. faecium resistant to Pen, Tc, macrolides, Sm and $\mathrm{Km}$ transferred $\mathrm{Tc}$ and at least one other resistance marker conjugatively. When Tc resistance was transferred alone, no detectable plasmid was seen in the Tc-resistant transconjugants. This phenomenon is strongly suggestive of a chromosomal location for the tet resistance-gene, and a conjugative transposon may be implicated in the conjugative process. However, the tet gene was not characterized, nor was the conjugative transposon (Le Bouguenec \& Horodniceanu, 1982).

There are numerous examples of drug-resistant clinical isolates that lack detectable plasmid DNA, yet in some of these cases the resistance determinant(s) was transferred by a process resembling conjugation (Clewell \& Gawron-Burke, 1986). One of the best-studied systems that involve a nonplasmid resistance transfer is that of $\mathrm{Tn} 916$, a Tc-resistant transposon originally described in Enterococcus faecalis DS16 and containing the tet $M$ determinant (Franke \& Clewell, 1981; Gawron-Burke et al., 1986). This $16.4 \mathrm{~kb}$ conjugative transposon, appears to encode information for its own transfer and transposition functions (Senghas et al., 1988). In addition, Tn916 upon transfer can insert itself in a variety of locations in the chromosome of transconjugants of various species (Gawron-Burke \& Clewell, 1982; Gawron-Burke et al., 1986); its transfer is a Rec-independent function and its can transfer from the chromosome to an E. faecalis haemolysin plasmid where it inserts within locations that result in hyperexpression or

† Present address: Istituto di Microbiologia, Via Laterina 8, 53100 Siena, Italy. 
hypoexpression of the haemolysis gene (Franke \& Clewell, 1981; Gawron-Burke \& Clewell, 1982).

The initial description of $\operatorname{Tn} 916$ ushered in an era where dissemination of similar elements has been demonstrated in other Gram-positive bacteria (Clewell \& Gawron-Burke, 1986; Christie et al., 1987; Murray et al., 1988). In this report we describe Tn916-like conjugative Tc-resistant elements in three clinical isolates of E. faecium. A fourth isolate contains a $\mathrm{Tn} 916$ homologous element on a large non-conjugative plasmid.

\section{METHODS}

Bacterial strains, media and reagents. The bacterial strains used in this study are listed in Table 1. Clinical isolates were obtained from Children's Hospital of Philadelphia $(\mathrm{CH} 1, \mathrm{CH} 2, \mathrm{CH} 3$ and $\mathrm{CH} 4$; kindly provided by $\mathrm{Dr} \mathrm{J}$. Campos), St Christopher's Hospital of Philadelphia (SC1, SC2, SC3, SC4 and SC5; kindly provided by Dr J. Mortensen) and New York City Hospital (SF8; kindly provided by Dr G. Dunny, Cornell University). All clinical isolates were identified by the Rapid Strep method (API Analytab Products).

Enterococci were grown in Todd-Hewitt broth (THB; Difco) supplemented with L-cysteine ( $0.1 \%$ ) and dextrose $(2 \%, \mathrm{w} / \mathrm{v})$. When present in selective agar plates, antibiotics were used at the following concentrations $\left(\mu \mathrm{g} \mathrm{ml}^{-1}\right)$ : $\mathrm{Tc}, 5 ; \mathrm{Em}, 10$; rifampin (Rif), 25; fusidic acid ( $\mathrm{Fa}$ ), 25; Sm, 500; spectinomycin (Sp), 500. MICs of antibiotics were determined by the tube dilution method in Antibiotic Medium or Mueller-Hinton broth and/or by the Grampositive MIC panel (American MicroScan). Antibiotics were obtained from Sigma.

Mating procedures. Filter matings were done essentially as previously described (Franke \& Clewell, 1981). An overnight donor culture $(0.05 \mathrm{ml})$ and recipient culture $(0.5 \mathrm{ml})$ were mixed in $4.5 \mathrm{ml}$ fresh THB and cells were collected on a membrane filter (cellulosic white plain $0.45 \mu \mathrm{m}$; Micron Sep). The filters were placed on tryptone soya agar (TSA) plates with $5 \%(\mathrm{v} / \mathrm{v})$ sheep blood (BBL) and allowed to incubate at $37^{\circ} \mathrm{C}$ for 18 to $20 \mathrm{~h}$. The cells were then suspended in $0.5 \mathrm{ml} \mathrm{THB}$, and the suspension was spread on antibiotic-containing plates selective for growth of transconjugants. Plates were examined after $48 \mathrm{~h}$ incubation. Donors and recipients were also incubated on antibiotic plates to check for effectiveness of the counterselection. Separate platings where donors alone were plated provided a base for estimating transfer frequency. In experiments using $E$. hirae $9790 \mathrm{RF}$ and $E$. faecalis JH2-2 as recipients, the transfer of Tc was not affected by the presence of DNAase $\left(100 \mu \mathrm{g} \mathrm{ml}^{-1}\right)$ and no transfer was detected in broth matings when recipient cells were plated with cell-free supernatants from donor bacteria.

$D N A$ preparation and characterization. Cells were lysed by a modification of the procedure of Le Bouguenec \& Horodniceanu (1982). Sedimented cells from a $200 \mathrm{ml} 18 \mathrm{~h}$ broth culture were suspended in $7.5 \mathrm{ml} 25 \%(\mathrm{w} / \mathrm{v})$ glucose in ET buffer (0.005 M-disodium EDTA, $0.01 \mathrm{M}$-Tris/ $\mathrm{HCl}, \mathrm{pH} 8.5)$; lysozyme (Boehringer) was then added at a final concentration of $2.5 \mathrm{mg} \mathrm{ml}^{-1}$. After $1 \mathrm{~h}$ at $37^{\circ} \mathrm{C}$, pre-digested Pronase (Calbiochem; $1.2 \mathrm{mg} \mathrm{ml}^{-1}$ final concentration) was added and the mixture incubated for $30 \mathrm{~min}$ at $37^{\circ} \mathrm{C}$. The protoplast mixture was then treated with RNAase (Millipore) at a final concentration of $0.1 \mathrm{mg} \mathrm{ml}^{-1}$. After $15 \mathrm{~min}$ at $37^{\circ} \mathrm{C}$, protoplasts were lysed by the addition of SDS (BDH) at a $1 \%$ final concentration. Plasmid-enriched DNA was prepared in the presence of $1 \mathrm{M}-\mathrm{NaCl}$ at $4{ }^{\circ} \mathrm{C}$ for 16 to $18 \mathrm{~h}$. Macromolecules and some chromosomal DNA was removed by centrifugation at 18000 r.p.m. for $30 \mathrm{~min}$. Isolation of plasmid DNA was by equilibrium centrifugation of SDS lysates in ethidium bromide- $\mathrm{CsCl}$ gradients essentially as described by Maniatis et al. (1982). Chromosomal DNA was extracted from SDS-lysed cells by precipitation of DNA with cold ethanol and spooling on a glass rod (Rodriguez \& Tait, 1983).

\section{Table 1. Bacterial strains used in this study}

\begin{tabular}{|c|c|c|c|}
\hline Strain & $\begin{array}{l}\text { Relevant chro! osome } \\
\text { markers }\end{array}$ & Plasmid content & $\begin{array}{l}\text { Source or } \\
\text { reference }\end{array}$ \\
\hline $\begin{array}{l}\text { E. faecium } \\
\text { 19434 } \\
\text { 19434RF }\end{array}$ & $\begin{array}{l}\text { None } \\
\text { rif fus }\end{array}$ & $\begin{array}{l}\text { None } \\
\text { None }\end{array}$ & $\begin{array}{l}\text { ATCC } \\
\text { This study }\end{array}$ \\
\hline $\begin{array}{l}\text { E. hirae } \\
\text { 9790 } \\
\text { 9790RF } \\
\text { 9790SS }\end{array}$ & $\begin{array}{l}\text { rif fus } \\
\text { str } s p c\end{array}$ & $\begin{array}{l}30 \mathrm{~kb} \text { cryptic plasmid } \\
30 \mathrm{~kb} \text { cryptic plasmid } \\
30 \mathrm{~kb} \text { cryptic plasmid }\end{array}$ & $\begin{array}{l}\text { ATCC } \\
\text { This study } \\
\text { This study }\end{array}$ \\
\hline $\begin{array}{l}\text { E. faecalis } \\
\text { JH2-2 } \\
\text { JH2SS } \\
\text { FA2-2 } \\
\text { UV202 }\end{array}$ & $\begin{array}{l}\text { rif fus } \\
\text { str spc } \\
\text { rif fus } \\
\text { rif fus }\end{array}$ & $\begin{array}{l}\text { None } \\
\text { None } \\
\text { pAM714 (pAD1: :Tn917) } \\
\text { None }\end{array}$ & $\begin{array}{l}\text { Franke \& Clewell (1981) } \\
\text { Tomich et al. (1978) } \\
\text { Ike \& Clewell (1984) } \\
\text { Franke \& Clewell (1981) }\end{array}$ \\
\hline
\end{tabular}


Agarose gel electrophoresis was done in a horizontal gel apparatus (model HE 99; Hoefer Scientific Instruments). Samples were loaded into wells in a $0.7 \%$ agarose gel and electrophoresed at $30 \mathrm{~V}$ for 14 to $20 \mathrm{~h}$. Electrophoresis was done at room temperature in TBE buffer $(0.089 \mathrm{M}$-Tris, $0.08 \mathrm{M}$-boric acid, $0.01 \mathrm{M}$-EDTA, $\mathrm{pH} \mathrm{8.0)}$. The gels were stained with a solution of ethidium bromide $\left(1 \mu \mathrm{g} \mathrm{ml}^{-1}\right)$ for $20 \mathrm{~min}$, and destained with $1 \mathrm{mM}-\mathrm{MgSO}_{4}$ for $45 \mathrm{~min}$ at room temperature.

Restriction endonucleases. DNA was digested with the following enzymes as specified by the manufacturer: HindIII, HincII and EcoRI (all from International Biotechnologies Inc.).

DNA-DNA hybridization. DNA blot transfer utilized the Vacu-Blot transfer system (model Vac-1000; American Bionetics) and was done by the method of Southern (1975). Hybridization was done at $68{ }^{\circ} \mathrm{C}$ and the blot was washed at $50{ }^{\circ} \mathrm{C}$ with $0.1 \times \mathrm{SSC}(1 \times \mathrm{SSC}$ is $0.15 \mathrm{M}-\mathrm{NaCl}, 0.015 \mathrm{M}$-sodium citrate, $\mathrm{pH} 7.0)$ and $0.1 \% \mathrm{SDS}$. The following probes were used in hybridization experiments: (i) pAM150 (Gawron-Burke \& Clewell, 1984), which carries the conjugative transposon Tn916; (ii) the $4.8 \mathrm{~kb}$ HincII fragment of pAM150 which contains the tet $M$ determinant of Tn916 (Gawron-Burke et al., 1986); (iii) pMV158 (Burdett et al., 1982), which carries the tet $L$ gene. Plasmid DNA labelled with $\left[\alpha^{-32} \mathrm{P}\right] \mathrm{dCTP}$ (ICN Radiochemicals) was prepared using the Multiprime DNA labelling system (Amersham). Autoradiography was done at $-70^{\circ} \mathrm{C}$ using a Du Pont Cronex intensifying screen.

\section{RESULTS}

Table 2 shows the antimicrobial-susceptibility patterns of 10 clinical isolates of $E$. faecium, and of the type strain ATCC 19434. Eight of ten clinical isolates were resistant to Em and clindamycin $(\mathrm{Cl})$. The same eight isolates were resistant to ampicillin (Am) and Pen. All but one isolate were resistant to Tc. Four had a high level of resistance $\left(128 \mu \mathrm{g} \mathrm{ml}^{-1}\right)$ and five had a low level of resistance ( 8 to $16 \mu \mathrm{g} \mathrm{m}^{-1}$ ). An apparent, naturally occurring, low-level gentamicin $(\mathrm{Gm})$ resistance was found in all the clinical isolates and in the ATCC strain. All clinical isolates exhibited a high level of resistance to Sm and eight out of ten were resistant to $\mathrm{Km}$.

In streptococci the tet $L$ gene confers resistance to $\mathrm{Tc}$ but not to minocycline (Mi), whereas the tet $M$ gene confers resistance to both antibiotics (Burdett et al., 1982). Table 2 shows that all nine clinical isolates resistant to $\mathrm{Tc}$ were also relatively resistant to $\mathrm{Mi}$.

Fig. 1 (a) shows that cellular DNA from $\mathrm{CH} 1, \mathrm{CH} 3$ and SF8 contains several similar plasmids smaller than about $10 \mathrm{~kb}$. $\mathrm{CH} 2, \mathrm{CH} 4$ and $\mathrm{SC} 1$ contain a limited number of small plasmids, and SC2, SC3, SC4 and SC5 have no detectable small plasmids. Although not necessarily shown in Fig. $1(a)$ all isolates contain a large plasmid over $30 \mathrm{~kb}$ in size. Fig. $1(b)$ shows the results of a Southern blot of the same material hybridized with a probe consisting of a $4.8 \mathrm{~kb}$ HincII fragment of Tn916 containing the tet $M$ determinant (Gawron-Burke et al., 1986). In CH1, CH3 and SF8 the probe hybridized to the chromosome only whereas in SC4 the same probe hybridized to the large plasmid as well as with linear DNA. None of the other isolates showed homology with tet $M$. pMV158 carrying tet $L$ did not hybridize with any DNA from the clinical isolates (not shown).

A chromosomal location for the tet $M$ determinant in $\mathrm{CH} 1, \mathrm{CH} 3$ and SF8 was confirmed by several additional experiments involving DNA isolated and fractionated by spooling (Rodriguez \& Tait, 1983), a procedure that removes all detectable plasmid DNA or CsClpurified plasmid DNA. The tet $M$ probe hybridized to only chromosomal DNA (data not shown). In contrast, in SC4, the tet $M$ determinant appeared to be associated with a large plasmid (Fig. 1b).

Cellular DNA from $\mathrm{CH} 1, \mathrm{CH} 3$ and SF8, and plasmid-enriched DNA from SC4 that showed homology with $\operatorname{Tn} 916$ was cut with HindIII, a restriction enzyme that cuts $\operatorname{Tn} 916$ once within the tet $M$ determinant (Gawron-Burke \& Clewell, 1982). CH1, CH3 and SF8 gave two indistinguishable junction fragments, 10.8 and $14.5 \mathrm{~kb}$ in size, whereas SC4 gave two entirely different junction fragments, 3.4 and $17.5 \mathrm{~kb}$ in size (Fig. 2). The presence of only two junction fragments in SC4 is inconsistent with the insertion of a tet $M$ determinant in both a plasmid and the chromosome. Therefore the linear DNA fragment, hybridizing with tet $M$ in Fig. 1 (b), lane $I^{\prime}$, most likely represents linearized plasmid DNA. A HindIII/EcoRI double digest of DNA from $\mathrm{CH} 1, \mathrm{CH} 3$ and SF8 gave two indistinguishable junction fragments, about 6.8 and $9.3 \mathrm{~kb}$, whereas the HindIII/EcoRI digest of SC4 gave two junction fragments, 9.2 and $3.4 \mathrm{~kb}$.

Tn916 has five internal HincII fragments (Yamamoto et al., 1987; Senghas et al., 1988). When 

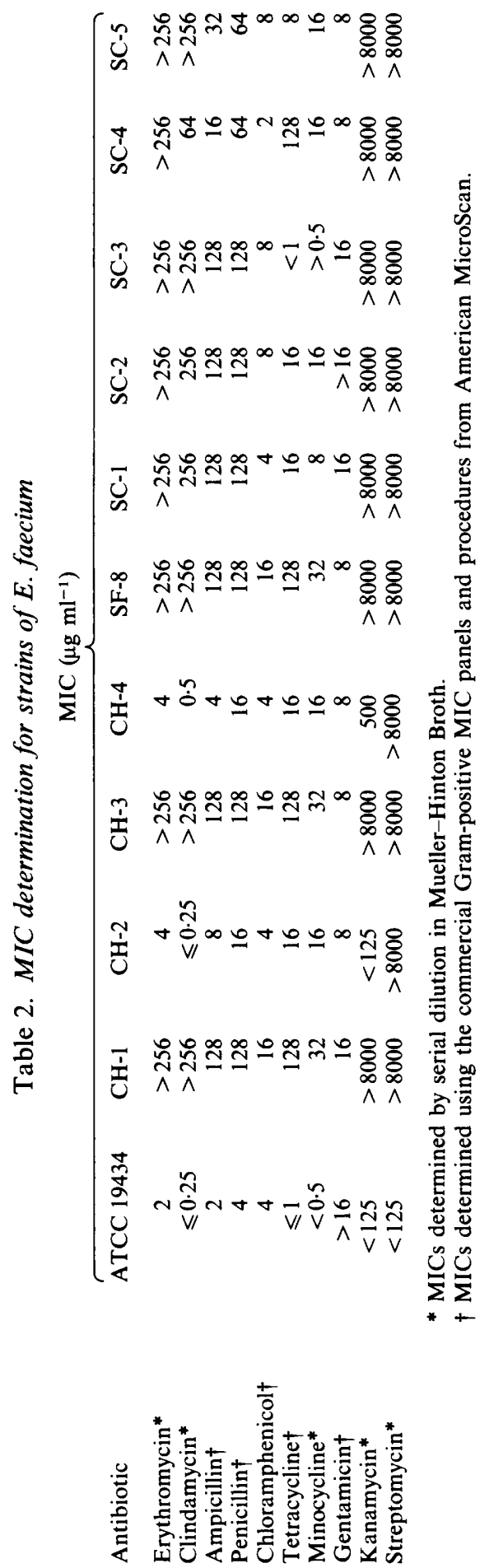
(a)
A
C
D
$\mathrm{F}$
$\begin{array}{lll}H & \mathrm{I} & \mathrm{J}\end{array}$

(b)

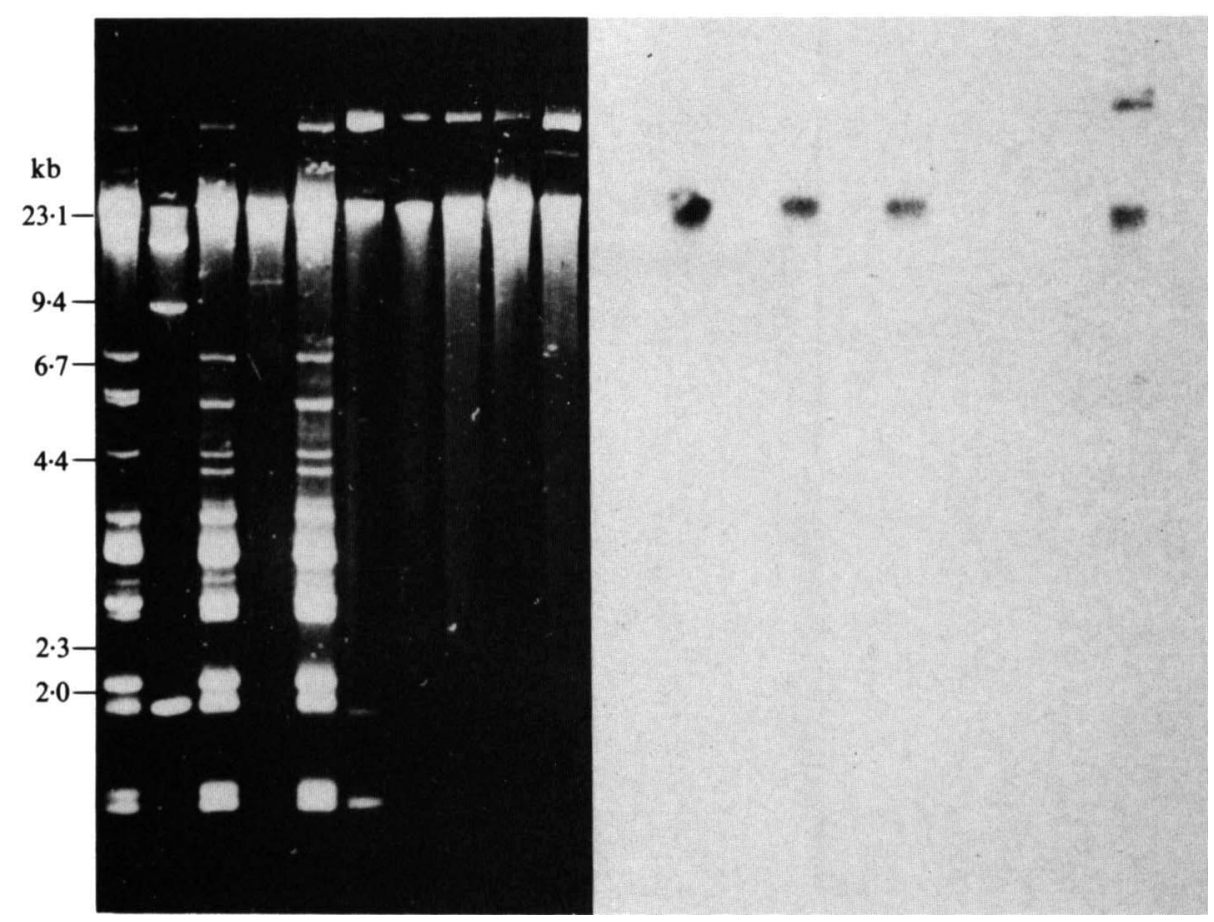

Fig. 1. (a) Agarose gel $(0.7 \%)$ electrophoresis of cellular DNA isolated from clinical isolates of E. faecium. Lanes A to D show $\mathrm{CH} 1, \mathrm{CH} 2, \mathrm{CH} 3$ and $\mathrm{CH} 4$ respectively. Lane E shows SF8 and lanes $\mathrm{F}$ to J show SC1, SC2, SC3, SC4 and SC5 respectively. (b) Autoradiogram obtained after Southern transfer of DNA from the agarose gel in panel (a), followed by hybridization with the ${ }^{32} \mathrm{P}$-labelled $4.8 \mathrm{~kb}$ HincII fragment of pAM150 (see Methods).

HincII-digested DNA of $\mathrm{CH} 1, \mathrm{CH} 3, \mathrm{SF} 8$ and SC4 was probed with pAM150, homology was detected in $\mathrm{CH} 1, \mathrm{CH} 3$ and SG8 on the fragments which were the same size as the five internal HincII fragments of Tn916 (Fig. 3). For SC4, homology was detected on only four such fragments. Further, a $4.8 \mathrm{~kb}$ fragment was missing, but a new 7.3 and a $2.1 \mathrm{~kb}$ band was seen. An external $3.2 \mathrm{~kb}$ fragment not present in Tn916 was seen in $\mathrm{CH} 1, \mathrm{CH} 3$ and SF8 (Fig. 3). When the $4.8 \mathrm{~kb}$ HincII fragment of pAM150, which contains the tet $M$ determinant, was used as a probe, homology was detected on the $4.8 \mathrm{~kb}$ HincII fragment in $\mathrm{CH} 1, \mathrm{CH} 3$ and SF8, in contrast to the $7.3 \mathrm{~kb}$ HincII fragment in SC4 (data not shown). Thus $\mathrm{CH} 1, \mathrm{CH} 3$ and SF8 showed the same HincII profile. It is to be noted that $\mathrm{CH} 1$ and $\mathrm{CH} 3$ were isolated from the same hospital, but two years apart from each other, whereas SF8 was isolated in New York City several years previously. Nevertheless, the data from the HindIII, HindIII/EcoRI and HincII digestions indicate that the determinant similar to Tn916 occupies apparently the same location in the chromosome of $\mathrm{CH} 1, \mathrm{CH} 3$ and SF8.

That $\mathrm{CH} 1, \mathrm{CH} 3$ and $\mathrm{SF} 8$ are not re-isolates of the same strain was demonstrated by restriction polymorphism. Digestion of cellular DNA from the three isolates using AvaI yielded a $6.8 \mathrm{~kb}$ band evident only in $\mathrm{CH} 1$. A HindIII digest of the same DNA yielded a $2.7 \mathrm{~kb}$ band present only in $\mathrm{CH} 1$ and $\mathrm{CH} 3$. Further, an $E c o \mathrm{RI} /$ HindIII digest gave a $7.5 \mathrm{~kb}$ fragment unique only to $\mathrm{CH} 3$ (data not shown).

All 10 clinical isolates were used in conjugation experiments by the filter mating procedure. Recipients were E. faecalis JH2-2 and E. hirae $9790 \mathrm{RF}$, both resistant to Rif and Fa (Table 1). Those antibiotics and Tc, Em and Pen were used for counterselection. Table 3 is typical of the 


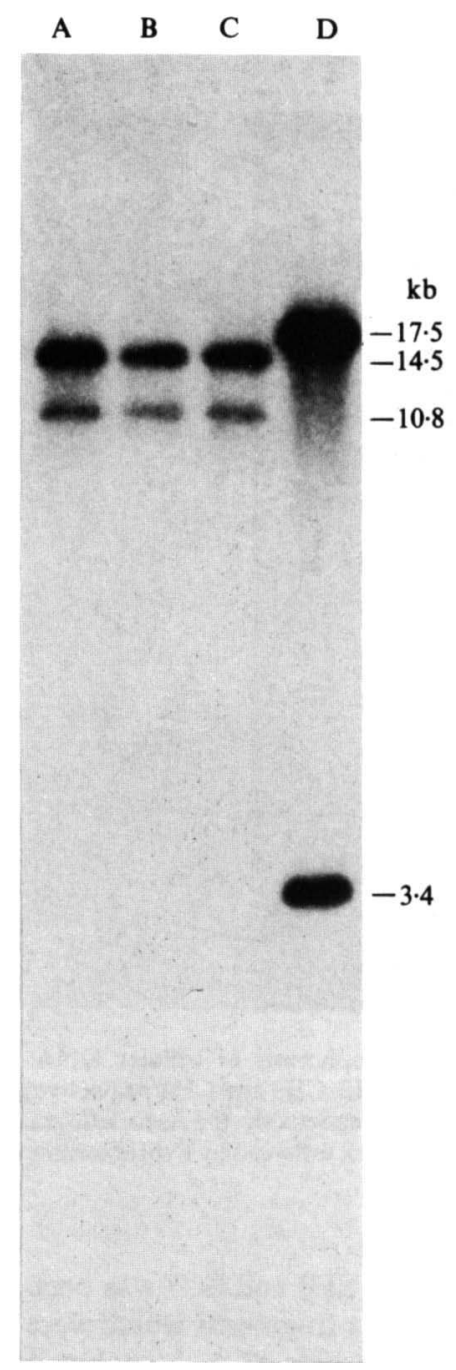

Fig. 2. Autoradiogram obtained from filter blot hybridization analyses of HindIII-digested DNA from clinical isolates of $E$. faecium. Lanes A, B and C show cellular DNA of CH1, CH3 and SF8 respectively. Lane D shows plasmid DNA of SC4. The probe was the ${ }^{32} \mathrm{P}$-labelled $4.8 \mathrm{~kb}$ HincII fragment of pAM150.

results obtained with either $E$. faecalis or E. hirae. $\mathrm{CH} 1, \mathrm{CH} 3$ and SF8 transferred only the tet marker at a frequency of $7.3 \times 10^{-6}, 8.6 \times 10^{-8}$ and $1.1 \times 10^{-7}$, respectively. None transferred pen. In some experiments $E$. faecium 19434RF (Table 1) was used as the recipient but no transfer was observed when $\mathrm{CH} 1, \mathrm{CH} 3$ or SF8 were used as donors. However, Tc resistance could be transferred conjugatively from an $E$. hirae transconjugant of $\mathrm{CH} 1$ to the Tc-susceptible E. faecium SC3. In each instance conjugal transfer was checked by determining the antimicrobial susceptibility pattern of a recipient as well as the recipient species.

Since all three isolates $(\mathrm{CH} 1, \mathrm{CH} 3$ and $\mathrm{SF} 8)$ contained a tet $M$-like determinant in an apparently identical chromosomal location, transconjugants were examined for location of the tet determinant, and for the effects of the position of the tet determinant on the ability to transfer the marker in a second round of matings. Fig. 4 shows the hybridization pattern of transconjugants from $\mathrm{CH} 1$ into $E$. hirae. The tet $M$-like determinants occur on more than one 


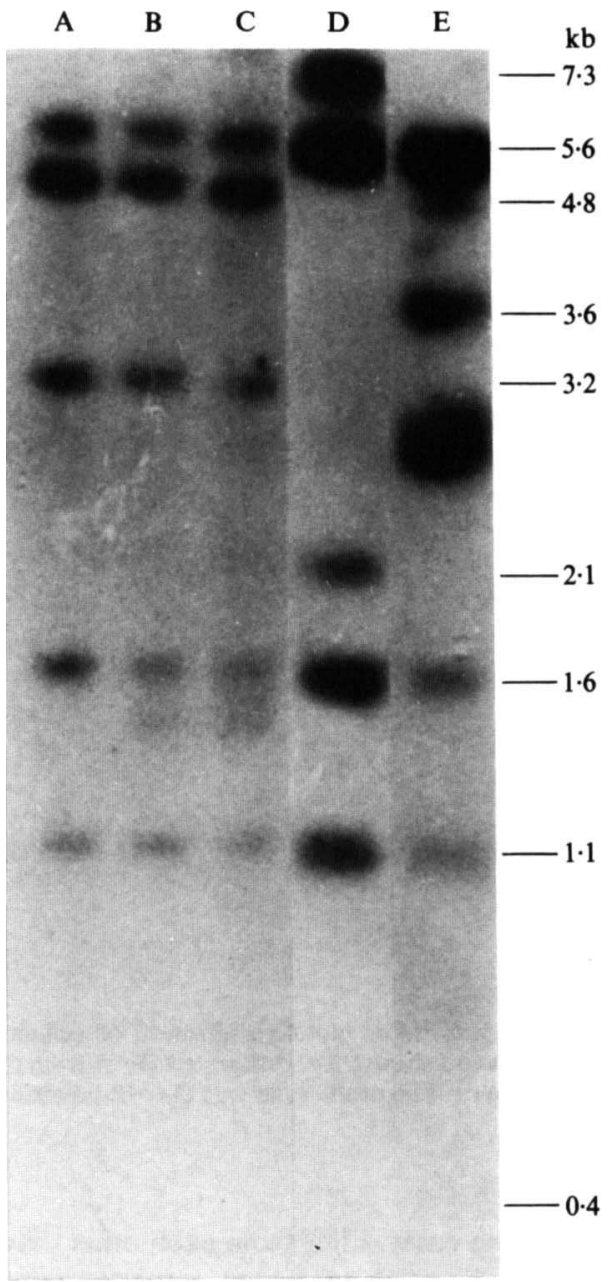

Fig. 3. Autoradiogram obtained from filter blot hybridization analysis of $H$ incll-digested DNA from $\mathrm{CH} 1, \mathrm{CH} 3, \mathrm{SF} 8, \mathrm{SC} 4$ and pAM150. Lanes A to $\mathrm{C}$ show cellular DNA of $\mathrm{CH} 1, \mathrm{CH} 3$ and SF8 respectively. Lane D shows plasmid DNA of SC4. Lane E shows pAM150. The sizes (kb) of the internal HincII fragments of Tn916 are as follows: $5.6,4.8,1 \cdot 6,1 \cdot 1$ and 0.4 . The $0.4 \mathrm{~kb}$ band is evident on prolonged exposure. The probe used was the ${ }^{32} \mathrm{P}$-labelled pAM150.

Table 3. Transfer of tetracycline-resistance from clinical isolates of E. faecium by conjugation

The transfer experiments involved overnight filter matings (see text)

\begin{tabular}{|c|c|c|c|c|}
\hline Donor & Recipient & Selection & $\begin{array}{c}\text { Transfer frequency/ } \\
\text { donor cell }\end{array}$ & $\begin{array}{l}\text { Phenotype of } \\
\text { transconjugants }\end{array}$ \\
\hline $\mathrm{CHI}$ & 9790RF & Rif, Fa, Tc & $7.3 \times 10^{-6}$ & $\operatorname{Rif}^{r} \mathrm{Fa}^{\mathrm{r}} \mathrm{Tc}^{\mathrm{r}}$ \\
\hline $\mathrm{CH} 2$ & 9790RF & Rif, Fa, Tc & $<2.8 \times 10^{-9}$ & - \\
\hline $\mathrm{CH} 3$ & 9790RF & Rif, Fa, Tc & $8.6 \times 10^{-8}$ & $\mathrm{Rif}^{r} \mathrm{Fa}^{r} \mathrm{Tc}^{\mathrm{r}}$ \\
\hline $\mathrm{CH} 4$ & 9790RF & Rif, Fa, Tc & $<2.7 \times 10^{-8}$ & - \\
\hline SF8 & 9790RF & Rif, Fa, Tc & $1.1 \times 10^{-7}$ & $\operatorname{Rif}^{r} \mathrm{Fa}^{r} \mathrm{Tc}^{r}$ \\
\hline $\mathrm{SCl}$ & 9790RF & Rif, Fa, Tc & $<2.2 \times 10^{-8}$ & - \\
\hline $\mathrm{SC} 2$ & 9790RF & Rif, Fa, Tc & $<2.2 \times 10^{-9}$ & - \\
\hline SC4 & 9790RF & Rif, Fa, Tc & $<1.3 \times 10^{-8}$ & - \\
\hline SC5 & 9790RF & Rif, Fa, Tc & $<1.2 \times 10^{-9}$ & - \\
\hline
\end{tabular}




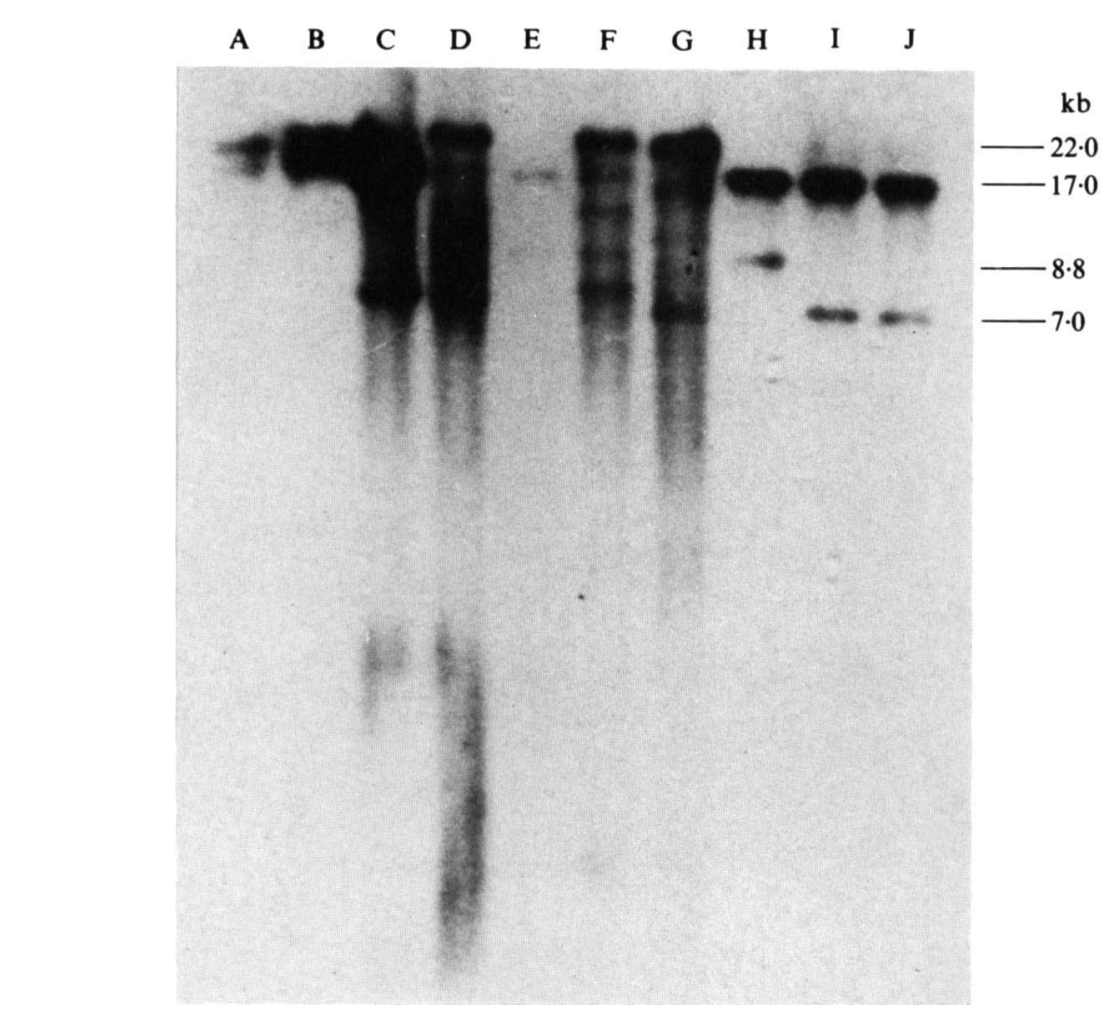

Fig. 4. Autoradiogram obtained from filter blot hybridization of cellular DNA from Tc-resistant transconjugants (Table 3). Lanes A to J show HindIII-digested DNA from transconjugants which were obtained using $\mathrm{CH}$ (Fig. 2) as donor. The probe used was the ${ }^{32} \mathrm{P}$-labelled $4.8 \mathrm{~kb}$ HincII fragment of pAM150.

chromosomal location and in some cases differ from each other. Five transconjugants (Fig. 4, lanes A, E, H, I and J) gave rise to two chromosome-transposon junction fragments, whereas five other transconjugants (Fig. 4, lanes B, C, D, F and G) gave rise to four or more bands. Similar results were obtained when $\mathrm{CH} 1$ was mated with $E$. faecalis. When an $E$. hirae transconjugant containing a Tn916-like element obtained from $\mathrm{CH}$ l was used as donor in a conjugation with $E$. faecium $\mathrm{SC}$, the marker was also transferred to the chromosome in a variety of locations (data not shown). Consequently, the tet $M$-like determinant that is transferred to recipients in filter matings can insert into several chromosomal locations and can occur in multiple copies in E. hirae, E. faecium and E. faecalis. Similar results were obtained for $\mathrm{CH} 3$ and SF8.

When 20 E. hirae $\mathrm{Tc}$-resistant transconjugants were examined for ability to conjugate further, 14 did and 6 did not, at least at detectable frequencies (data not shown). Those that did conjugate had conjugation frequencies $\left(10^{-6}\right.$ to $\left.10^{-8}\right)$ similar to the original donor strains (Table 3$)$. The location of the tet $M$-like determinant (as indicated by the sizes of HindIII-cut junction fragments hybridizing with tet $M$ ) did not appear to be specific for transconjugants capable or incapable of further matings. However, of six of the transconjugants that were capable of a second round mating five had between two and three insertions (see for example lanes B, C, D, F and $G$, in Fig. 4). In contrast, of six transconjugants that were incapable of a second round mating none had multiple insertions (see for example lanes A, E, H, I and J, in Fig. 4).

$\mathrm{CH} 1, \mathrm{CH} 3$ and SF8 were used as donors in overnight filter matings with the recombinationdeficient strain UV202, a derivative of E. faecalis JH2-2 (Franke \& Clewell, 1981). Tc-resistance was transferred to UV202 and to $\mathrm{JH} 2-2$ with comparable frequencies. 
Table 4. Transfer of tetracycline resistance from derivatives of either $\mathrm{CH1}$, CH3 or SF8 to JH2SS by conjugation

The transfer experiments involved overnight filter matings. JH2SS is a plasmid-free $\mathrm{Sm}^{r} \mathrm{Sp}^{r}$ strain (see text)

$\begin{array}{cccc}\begin{array}{c}\text { Donor } \\ \text { strain* }\end{array} & \begin{array}{c}\text { Plasmid } \\ \text { in donor }\end{array} & \begin{array}{c}\text { Transfer frequency/ } \\ \text { donor cell }\end{array} & \text { Haemolysin } \dagger(\%) \\ \text { HF14 } & \text { pAM714 } & 7.2 \times 10^{-7} & +^{\text {H }(3)} \\ & & & +(79) \\ \text { HF21 } & \text { pAM714 } & 2.6 \times 10^{-6} & +(18) \\ & & & +^{\text {H }}(4) \\ & & -(72) \\ \text { HF22 } & \text { pAM714 } & 2.9 \times 10^{-6} & +{ }^{H}(3) \\ & & & +(73) \\ & & & -(24)\end{array}$

${ }^{*} \mathrm{HF} 14, \mathrm{HF} 21$ and HF22 are tetracycline-resistant transconjugants from conjugation of $\mathrm{CH} 1, \mathrm{CH} 3$ and SF8, respectively, with $9790 \mathrm{RF}$.

$\dagger-$, Non-haemolytic; + , haemolytic on $5 \%(w / v)$ sheep-blood agar plates; $+^{H}$, hyperhaemolytic.

The Tn916-like determinant derived from $\mathrm{CH} 1, \mathrm{CH} 3$ and SF8 was examined for ability to affect expression of the haemolysin gene of pAM714 (pAD1 : :Tn917) (Ike \& Clewell, 1984). pAM714 was introduced into E. hirae 9790RF containing the Tn916-like element from $\mathrm{CH} 1$, $\mathrm{CH} 3$ or SF8. Each transconjugant was used as a donor in conjugations with JH2SS. Tc-resistant transconjugants were obtained with frequencies of $10^{-6}$ to $10^{-7}$ per donor cell (Table 4). Of these 3 to $4 \%$ were hyperhaemolytic. Some 18 to $24 \%$ of the Tc-resistant transconjugants showed loss of haemolysis (Table 4). An EcoRI restriction analysis of plasmid DNA in a hyperhaemolytic and a non-haemolytic transconjugant demonstrated the presence of a $16.5 \mathrm{~kb}$ insertion equivalent in size to $\mathrm{Tn} 916$. Further, in the hyperhaemolytic transconjugant the insertion was in the D fragment of the haemolysin gene (Ike \& Clewell, 1984).

\section{DISCUSSION}

Of the ten clinical isolates of E. faecium studied nine showed resistance to Tc and Mi. Four isolates had high-level resistance to both antibiotics and carried a Tn916-like element. Thus there is a correlation between high-level resistance to Tc and the presence of a Tn916-like element. This is consistent with previous reports on the level of resistance conferred by the tet $M$ gene (Burdett et al., 1982). It is noteworthy that none of the isolates showed similarity with the tet $L$ determinant. In a study in E. faecalis, Pepper et al. (1987) found homology with Tn 916 in all eight isolates (two on plasmids, six in the chromosome). In addition, three of the eight contained an element homologous to a tet $L$ probe. The $E$. faecalis isolates had MICs for Tc of 32 to $128 \mu \mathrm{g}$ $\mathrm{ml}^{-1}$. The low-level resistance seen here in five $E$. faecium isolates may be due to an as yet undescribed Tc-resistance determinant in enterococci.

Three of the four tet $M$-like elements examined here were clearly conjugative. They were localized in the chromosome and conjugated at a low frequency. One tet $M$-like element was found on a large non-conjugative plasmid. Further, this same plasmid contained the tet determinant on a $7.3 \mathrm{~kb}$ HincII fragment, in contrast to a $4.8 \mathrm{~kb}$ HincII fragment in the other three isolates and Tn916. Although fragments which were the same size as the internal HincII fragments of Tn916 were detected, no transposon function has yet been demonstrated. Tn916like elements in enterococci seem to occur mostly in the chromosome (reviewed in Clewell \& Gawron-Burke, 1986), but in rare cases they have been found on plasmids. The latter have been reported only in E. faecalis [pCF10 (Christie et al., 1987); pIP1440 (Pepper et al., 1987)].

We demonstrated that the Tn916-like element is a transposon in three ways: (1) it can be found in a variety of locations and frequently in more than one copy in transconjugants; (2) it 
transfers equally well in $\mathrm{Rec}^{+}$and $\mathrm{Rec}^{-}$enterococcal strains; (3) it can transfer from the chromosome to a haemolysin plasmid where it inserts within locations that results in hyperexpression or hypoexpression of the haemolysin gene.

To our knowledge, this report is the first to provide rigorous evidence of transposons with conjugative properties in E. faecium; hence we designate these transposons $\operatorname{Tn} 5031$, Tn5032 and $\mathrm{Tn} 5033$. The other conjugative transposons so far identified are Tn918 in E. faecalis (Clewell et al., 1985), Tn919 in Streptococcus sanguis (Fitzgerald \& Clewell, 1985), Tn920 and Tn925 in E. faecalis (Murray et al., 1988; Christie et al., 1987). All code for Tc-resistance and share homology with Tn916, a 16.4 kb element (Gawron-Burke \& Clewell, 1982; Franke \& Clewell, 1981).

Although the three chromosomal inserts appear to be in the same chromosomal location, this is not so in the transconjugants. We were puzzled to find a transposon in apparently the same location in three clinical isolates which show restriction polymorphism and were obtained at different times from different places. In Streptococcus pneumoniae and other streptococcal strains large transposon-like elements have been shown to contain several antibiotic resistance markers (Clewell \& Gawron-Burke, 1986). In some cases conjugative transfer of the resistance traits occurs en bloc, while in other cases only tet is transferred. Perhaps here only the Tn916-like element can conjugate, but the other resistant markers are present, providing common adjacent restriction sequences. Clewell et al. (1988) reported data suggestive of a non-replicative insertion mechanism where $\mathrm{Tn} 916$ contains a sequence partially homologous with the target sequence, which facilitates insertion of a circular intermediate of the transposon via a reciprocal recombination. Possibly a site in the clinical isolates contained homologous sequences facilitating insertion. However, our data indicate that in second round conjugations no specific sites were selected for transposon insertion even when an E. faecium strain was used as the recipient.

We thank Dr J. Campos, Dr J. Mortensen and Dr G. Dunny for providing us with clinical isolates of Enterococcus faecium. We are grateful to Dr D. B. Clewell for helpful suggestions and the gift of JH2-2, JH2SS, UV202, FA2-2 and CG150 harbouring pAM150, and to Dr V. Burdett for JH2-2 harbouring pMV158 or pMV120.

\section{REFERENCES}

Burdett, V., Inamine, J. \& Rajagopalan, S. (1982). Heterogeneity of tetracycline resistance determinants in Streptococcus. Journal of Bacteriology 149 , 995-1004.

Christie, P. J., Korman, R. Z., Zahler, S. A., Adsit, J. C. \& DUNNY, G. M. (1987). Two conjugation systems associated with Streptococcus faecalis plasmid pCF10: identification of a conjugative transposon that transfers between $S$. faecalis and Bacillus subtilis. Journal of Bacteriology 169, 2529-2536.

Clewell, D. B. \& Gawron-Burke, C. (1986). Conjugative transposons and the dissemination of antibiotic resistance in streptococci. Annual Review of Microbiology 40, 635-659.

Clewell, D. B., AN, F. Y., White, B. A. \& GawronBURKE, C. (1985). Streptococcus faecalis sex pheromone (cAM373) also produced by Staphylococcus aureus and identification of a conjugative transposon (Tn918). Journal of Bacteriology 162, 1212-1220.

Clewell, D. B., Senghas, E., Jones, J. M., Flannagan, S. E., Yamamoto, M. \& GawronBURKE, C. (1988). Transpositon in Streptococcus: structural and genetic properties of the conjugative transposon Tn916. In Transposition, 43rd Symposium of the Society for General Microbiology, pp. 43-58. Edited by A. J. Kingsman, K. F. Chater \& S. M. Kingsman. Cambridge: Cambridge University Press.

Finland, M. (1979). Emergence of antibiotic resistance in hospitals, 1935-1975. Reviews in Infectious Diseases 1, 4-21.

Fitzgerald, G. F. \& Clewell, D. B. (1985). A conjugative transposon (Tn 919) in Streptococcus sanguis. Infection and Immunity 47, 415-420.

Franke, A. E. \& Clewell, D. B. (1981). Evidence for a chromosome-borne resistance transposon (Tn 916) in Streptococcus faecalis that is capable of "conjugal" transfer in the absence of a conjugative plasmid. Journal of Bacteriology 145, 494502.

Gawron-Burke, C. \& Clewell, D. B. (1982). A transposon in Streptococcus faecalis with fertility properties. Nature, London 300, 281-284.

Gawron-Burke, C. \& Clewell, D. B. (1984). Regeneration of insertionally inactivated streptococcal DNA fragments after excision of transposon Tn916 in Escherichia coli: strategy for targeting and cloning of genes from Gram-positive bacteria. Journal of Bacteriology 159, 214-221.

Gawron-Burke, C., Wirth, R., Yamamoto, M., Flannagan, S., Fitzgerald, G., AN, F. \& Clewell, D. B. (1986). Properties of the streptococcal transposon Tn916. In Molecular Microbiology and Immunology of Streptococcus mutans. Edited by S. Hamada and others. Amsterdam: Elsevier Science Publishers. 
IKE, Y. \& CLEWELL, D. B. (1984). Genetic analysis of pAD1 pheromone response in Streptococcus faecium using transposon $\operatorname{Tn} 917$ as an insertional mutagen. Journal of Bacteriology 158, 777-783.

Le Bouguenec, C. \& Horodniceanu, T. (1982). Conjugative $\mathbf{R}$ plasmids in Streptococcus faecium (group D). Antimicrobial Agents and Chemotherapy 21, 698-705.

Maniatis, T., Fritsch, E. F. \& SAMbrooK, J. (1982). Molecular Cloning: A Laboratory Manual. Cold Spring Harbor, NY: Cold Spring Harbor Laboratory.

Murray, B. E., AN, F. Y. \& Clewell, D. B. (1988). Plasmids and pheromone response of the betalactamase producer Streptococcus (Enterococcus) faecalis HH22. Antimicrobial Agents and Chemotherapy 32, 547-551.

Pepper, K., Horaud, T., Le Bouguen-r. C. \& De Cespedes, G. (1987). Location of antibiotic resistance markers in clinical isolates of Enterococcus faecalis with similar antibiotypes. Antimicrobial Agents and Chemotherapy 31, 1394-1402.
RoDRIGUEZ, R. L. \& TAIT, R. C. (1983). Recombinant DNA techniques. Menlo, CA: The Benjamin/ Cumming Publishing Co.

Senghas, E., Jones, J. M., Yamamoto, M., GawronBurke, C. \& Clewell, D. B. (1988). Genetic organization of the bacterial conjugative transposon Tn916. Journal of Bacteriology 170, 245-249.

SOUTHERN, E. M. (1975). Detection of specific sequences among DNA fragments separated by gel electrophoresis. Journal of Molecular Biology 58, 503-517.

Toмich, P. K., AN, F. \& Clewell, D. B. (1978). Properties of erythromycin-inducible transposon Tn917 in Streptococcus faecalis. Journal of Bacteriology 141, 1366-1374.

Yamamoto, M., Jones, J. M., Senghas, E., GawronBurke, C. \& Clewell, D. B. (1987). Generation of Tn5 insertions in streptococcal conjugative transposon Tn916. Environmental Microbiology 53, 1069-1072. 